\title{
Reproductive Health Status and Health Seeking Behavior of Adolescent Girls in Selected Urban Slum of Dhaka City in Bangladesh
}

\author{
Syeda Saima Alam ${ }^{1 *}$, Md Nahian Rahman ${ }^{1}$, Md Ahad Mia², Md Monoarul Haque ${ }^{3}$ and Khaleda Islam ${ }^{3}$ \\ ${ }^{1,2,3}$ MS in Nutrition and Food Science, University of Dhaka, Bangladesh
}

${ }^{2}$ PhD Research Fellow, Bangladesh University of Professionals, Bangladesh

${ }^{3}$ Professor, University of Dhaka, Bangladesh

Submission: July 5, 2018; Published: July 31, 2018

*Corresponding author: Syeda Saima Alam, MS in Nutrition and Food Science, University of Dhaka, Bangladesh; Email: gpabd17@gmail.com

\begin{abstract}
Adolescent girls are the mothers of tomorrow and no edifice can be built on a foundation which is so weak. The purpose of this study was to assess reproductive health status and health seeking behavior of the adolescent girls. A cross-sectional study was carried out among adolescent girls 10-19 years $(n=150)$ in the selected slum areas in Dhaka city. Structured questionnaires were used to obtain information on socio-demographic characteristics, reproductive health status and health seeking behavior. Based on this assessment, the majority of the girls (50\%) were in the age group 10-13 years (early adolescence), while 30\% were in the age group 14-16 years (middle adolescence) and $19.3 \%$ were in the age group $17-19$ years (late adolescence). About $72.7 \%$ of the respondents were students and $24 \%$ of the adolescent girls worked in garments. The mean income of these slum households was approximately 19650 BDT per month. Among the adolescent girls, 58.7\% of the girls suffered from general health problem while $34.7 \%$ of the girls suffered from reproductive health problem. Almost $34 \%$ of the girls did not seek treatment for their health problems. Those who sought for treatments were mainly dependent on pharmacy attendants (61.7\%) for remedies. About $62 \%$ of the adolescent girls had an idea about menstruation cycle.

The mean age of the girls who had their menstruation was 12 years. About $67 \%$ of the girls used cloth during menstruation and $90.5 \%$ of the girls said that they did not follow proper procedure to clean the cloth. About $85.3 \%$ of the adolescent girls did not take any vaccination. Study indicates that among the adolescent girls those who used cloths during their menstruation, only $9.5 \%$ girls cleaned the cloth properly.45\% of the girls isolated themselves during the menstruation. Again $57.4 \%$ of the adolescent girls told that they avoid food items due to the foul smell, taboo, and anorexia during menstruation. There was a negative correlation between nutritional status and health issues of the adolescent girls as like dietary diversity.
\end{abstract}

Keywords: Reproductive health status; Health seeking behavior; Adolescent girls; Urban slum

\section{Introduction}

Adolescence is the transition period between childhood and adulthood. It is a period of life with specific health and developmental needs and rights [1]. To accommodate the different phases of development in the second decade of life, adolescence is often divided into early (10-13 years), middle (14-16 years) and late (17-19 years) adolescence [2]. They comprise $20 \%$ of the global population and about $80 \%$ of them live in developing countries like Bangladesh [3]. Among adolescents, adolescent girls experience more health-related problems and inequalities than others. They are deprived in all areas, including within the spheres of social status, economic power, and culture, and are ignored by the mainstream people.
As a result, they are deprived of their essential needs. Hence, they are more vulnerable because of their social status. Health and nutrition knowledge and healthy habits of female adolescents will have critical roles to play in maintaining future family health and nutrition. At present, 1.5 million people live in slums within two or two and a half miles radius of the city. The living conditions of these slums are inhuman. The slum dwellers are also deprived of primary health care facilities. There is no medical center for them. The child death rate is unusually high, more than 15 percent. Most of the children suffer from malnutrition (Rahman, 2015) [4]. Most of the slum dwellers in Dhaka came from the poorest districts of our country. Majority of the slum dwellers come because of river 


\section{Global Journal of Reproductive Medicine}

erosion, rough, famine, better income etc. slum dwellers migrate to Dhaka seeking a better life and job opportunities that the city offers.

\section{Methodology}

The study was a cross-sectional study. The study was conducted among 150 adolescent girls in the selected urban area in Dhaka. The study was conducted in the slum area of mailbag, Santibag, and Mirpur from October 2017 to February 2018. For the study, a sample of 150 respondents was purposely selected to collect information on the proposed study. The respondents must be an adolescent girl age of 10-19 years, urban slum area and willing to participate in the study were included and those not willing to participate in the study, refusal from the family and demand money to participate were excluded. The purpose and nature of the study were explained to each participant and after getting the verbal consent, they were included in the study. The selected 150 girls were interviewed by pretested questionnaire.

A standard questionnaire was developed to obtain the relevant information. Different types of variables were taken to see the association by using statistics. Health seeking behavior refers to the sequence of remedial actions that individuals undertake to rectify perceived ill health. Reproductive health refers to the rights of men and women to be informed and have access to safe, effective, affordable and acceptable methods of fertility regulation of their choice and the rights of access to appropriate health care services that will enable women to go safely through pregnancy and childbirth. In short, reproductive health addresses reproductive process, functions, and systems at all stages of life [5]. Ethical guidelines of Declaration of Helsinki IV were followed throughout the study. The questionnaire was designed considering the privacy of the subject. The subject's personal information was kept confidential.

\section{Results}

Table- 1 shows the number of adolescent girls aged between 10 to 19 years. About $50 \%$ were aged between $10-13$ years, $30.7 \%$ were aged between 14-16 years and $19.3 \%$ were aged between $17-19$ years. This Figure 1 presents that about $22.7 \%$ of the girls passed the classes less than class $3,42 \%$ of the girls passed the classes 3 to $5,16 \%$ of the girls passed the classes 6 to $8,12.7 \%$ of the girls passed classes 8 to 10 and $6.7 \%$ girls passed SSC. Figure 2 presents the findings related to the occupation of the respondents. Majority of the respondents $(72.7 \%)$ were students. $24 \%$ of the girls were garments workers and only $3.3 \%$ of the girls worked in others' homes. The Figure 3 shows that about $31.3 \%$ of the families earned between 17000-25000 taka per month.26.7\% of the families earned less than 1400 taka, $26.7 \%$ families earned between 14000-17000 taka and only 18\% families earned more than 25000 taka. This Table 2 illustrates that about $58.7 \%$ of the adolescent girls suffered from general health problem and $34.7 \%$ of the adolescent girls suffered from a reproductive health problem in last three months. This Table 3 depicts that about half $(48.9 \%)$ of the adolescent girls suffered from fever and rest of them suffered from various kinds of diseases. Among them, running nose $(18.2 \%)$, cough $(12.5 \%)$ were more frequent. Findings reveal that about $70 \%$ of the adolescent girls who had their menstruation suffered from abdominal pain.

Table 1: Distribution of the adolescent girls aged between 10 to 19 years $(n=150)$.

\begin{tabular}{|c|c|c|}
\hline Age (years) & Frequency & Percentage \\
\hline Early adolescence (10-13 years) & 75 & 50 \\
\hline Middle adolescence (14-16 years) & 46 & 30.7 \\
\hline Late adolescence (17-19 years) & 29 & 19.3 \\
\hline Total & 150 & 100 \\
\hline
\end{tabular}

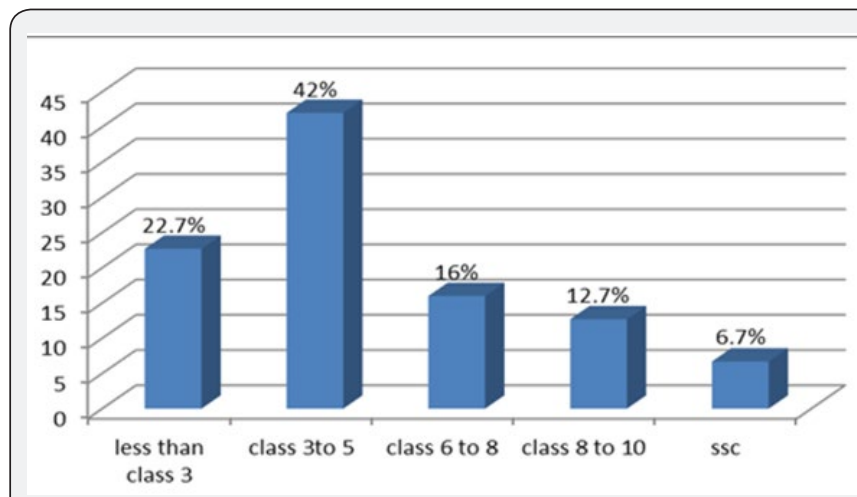

Figure 1: Distribution of educational status of the respondents $(n=150)$.

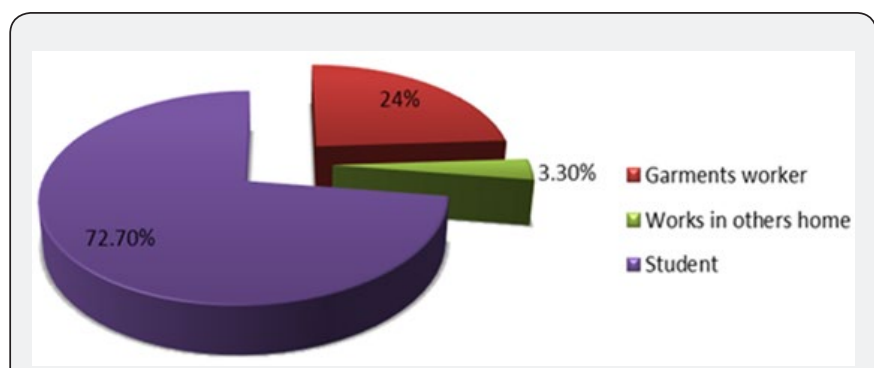

Figure 2: Distribution of occupation of the respondents ( $n=150)$

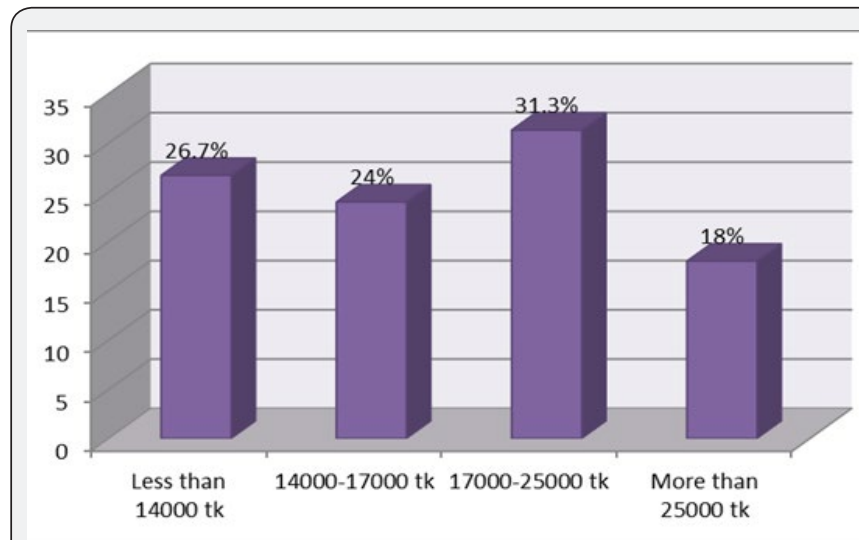

Figure 3: Total monthly income of the families of the respondents $(n=150)$. 


\section{Global Journal of Reproductive Medicine}

Table 2: Distribution of the number of adolescent girls suffer from any diseases during last 3 months $(n=150)$.

\begin{tabular}{|c|c|c|c|c|}
\hline $\begin{array}{c}\text { Suffering } \\
\text { from } \\
\text { diseases }\end{array}$ & \multicolumn{2}{|c|}{ General health problem } & \multicolumn{2}{c|}{$\begin{array}{c}\text { Reproductive health } \\
\text { problem }\end{array}$} \\
\cline { 2 - 5 } & Frequency & Percentage & Frequency & Percentage \\
\hline Yes & 88 & 58.7 & 52 & 34.7 \\
\hline No & 62 & 41.3 & 98 & 65.3 \\
\hline Total & 150 & 100 & 150 & 100 \\
\hline
\end{tabular}

Table 3: Pattern of diseases of the respondents suffered from general health problem $(n=150)$.

\begin{tabular}{|c|c|c|}
\hline Health problem & Frequency & Percentage \\
\hline Fever & 43 & 48.9 \\
\hline Cough & 11 & 12.5 \\
\hline Running nose & 16 & 18.2 \\
\hline Diarrhea & 3 & 3.4 \\
\hline Jaundice & 4 & 4.5 \\
\hline Gastric problem & 5 & 5.7 \\
\hline others & 6 & 6.8 \\
\hline Total & 88 & 100 \\
\hline
\end{tabular}

Table 4: Distribution of adolescent girls suffered from reproductive health problem $(n=150)$.

\begin{tabular}{|c|c|}
\hline Reproductive health problem & Percentage \\
\hline Abdominal pain & 70 \\
\hline Irregularity & 6.1 \\
\hline Lower back pain & 12.4 \\
\hline Bleeding more than 7 days & 9.6 \\
\hline Bleeding less than 3 days & 1.9 \\
\hline Total & 100 \\
\hline
\end{tabular}

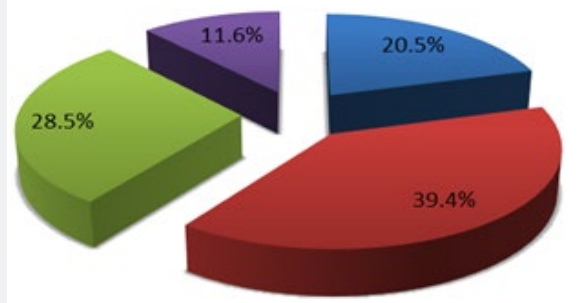

- 11 years

=12 years

\pm 13 years

=14 years

Figure 4: Distribution of adolescent girls considering their age of first menstruation $(n=150)$.

Table 5: Distribution of adolescent girls based on their response to diseases $(n=150)$.

\begin{tabular}{|c|c|}
\hline Answer of the respondents & Percentage \\
\hline Yes & 65.8 \\
\hline No & 34.2 \\
\hline Total & 100 \\
\hline
\end{tabular}

Table 6: Distribution of the adolescent girls by their treatment seeking behaviour $(n=150)$.

\begin{tabular}{|c|c|}
\hline Treatment seeking behavior & Percentage \\
\hline Self-treatment & 3.3 \\
\hline Mother's advice & 11.7 \\
\hline Pharmacy attendant & 61.7 \\
\hline Qualified doctor & 13.3 \\
\hline Homeopathy & 10 \\
\hline
\end{tabular}

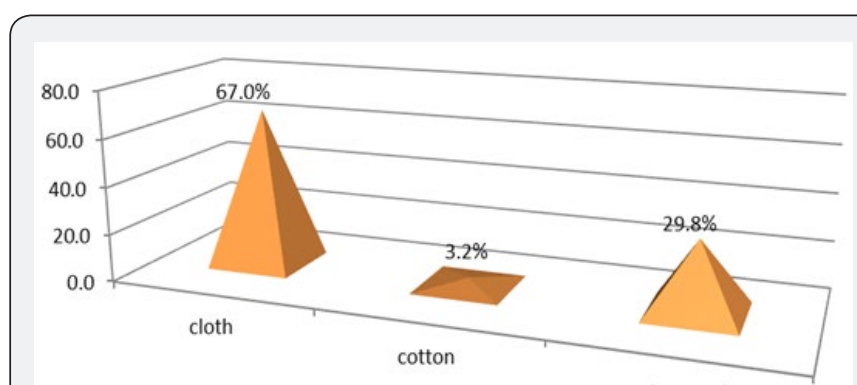

Figure 5: Using cloth, cotton and sanitary pad in menstruation during periods for the respondents $(n=150)$.

Table 7: Distribution of the adolescent girls by taking vaccination $(n=150)$.

\begin{tabular}{|c|c|}
\hline Name of the vaccination & Percentage \\
\hline Tetanus vaccine & 10.7 \\
\hline Hepatitis & 4 \\
\hline No vaccination & 85.3 \\
\hline Total & 100.0 \\
\hline
\end{tabular}

Table 8: Pattern of reproductive health behaviour $(n=150)$.

\begin{tabular}{|c|c|c|c|}
\hline Answer & $\begin{array}{c}\text { Cleaning } \\
\text { the cloth } \\
\text { properly } \\
\text { (\%) }\end{array}$ & $\begin{array}{c}\text { Isolation during } \\
\text { menstruation } \\
\text { time (\%) }\end{array}$ & $\begin{array}{c}\text { Avoiding } \\
\text { food item } \\
\text { (\%) }\end{array}$ \\
\hline Yes & 9.5 & 45.7 & 57.4 \\
\hline No & 90.5 & 54.3 & 42.6 \\
\hline Total & 100.0 & 100.0 & 100 \\
\hline
\end{tabular}

About $6.1 \%$ of the girls suffered from irregularity and $12.4 \%$ of the girls suffered from lower back pain (Table 4). Figure 4 shows that most of the girls (39.4\%) encountered their period at the age of 12 years followed by $28.5 \%$ at the age of 13 years, $20.5 \%$ at 11 years and $28.5 \%$ at 14 years. It has been observed that $65.8 \%$ of the adolescent girls sought for treatment where $34.2 \%$ did not seek any treatment (Table 5). Table 6 describes that $61 \%$ of the adolescent girls received treatment from pharmacy attendant, only $13.3 \%$ of the adolescent girls received treatment from a qualified doctor and $10 \%$ of the girls received medicine from homeopath doctor. It has been observed that majority of the girls (85.3\%) had not taken any vaccination. Only $10.7 \%$ had taken tetanus vaccine and $4 \%$ had taken hepatitis vaccine (Table 7). Figure 5 shows that, during periods, $67 \%$ of the respondents used cloth, $3.2 \%$ used cotton and $29.8 \%$ used a sanitary pad. Table 8 indicates that 


\section{Global Journal of Reproductive Medicine}

among the adolescent girls those who used cloths during their menstruation, only $9.5 \%$ girls cleaned the cloth properly. $45 \%$ of the girls isolated themselves during the menstruation. Again 57.4 $\%$ of the adolescent girls told that they avoid food items due to the foul smell, taboo, and anorexia during menstruation. There was a negative correlation between nutritional status and health issues of the adolescent girls (Table 9). There was a negative correlation between individual dietary diversity and health problem of the adolescent girls (Table 10).

Table 9: Relation between health problem and nutritional status (BAZ) of the adolescent girls $(n=150)$.

\begin{tabular}{|c|c|c|c|c|c|}
\hline \multicolumn{6}{|c|}{ Correlations } \\
\hline & & & BAZ category & $\begin{array}{l}\text { Suffered from general } \\
\text { health problem }\end{array}$ & $\begin{array}{c}\text { Suffered from } \\
\text { reproductive health } \\
\text { problem }\end{array}$ \\
\hline \multirow{9}{*}{$\begin{array}{l}\text { Spearman's } \\
\text { rho }\end{array}$} & \multirow{3}{*}{ BAZ category } & $\begin{array}{l}\text { Correlation } \\
\text { Coefficient }\end{array}$ & 1.000 & -.125 & $-.202^{*}$ \\
\hline & & Sig. (2-tailed) & . & .126 & .013 \\
\hline & & $\mathrm{N}$ & 150 & 150 & 150 \\
\hline & \multirow{3}{*}{$\begin{array}{c}\text { Suffered from } \\
\text { general health } \\
\text { problem }\end{array}$} & $\begin{array}{l}\text { Correlation } \\
\text { Coefficient }\end{array}$ & -.125 & 1.000 & .156 \\
\hline & & Sig. (2-tailed) & .126 & . & .056 \\
\hline & & $\mathrm{N}$ & 150 & 150 & 150 \\
\hline & \multirow{3}{*}{$\begin{array}{l}\text { Suffered from } \\
\text { reproductive } \\
\text { health problem }\end{array}$} & $\begin{array}{l}\text { Correlation } \\
\text { Coefficient }\end{array}$ & $-.202^{*}$ & .156 & 1.000 \\
\hline & & Sig. (2-tailed) & .013 & .056 & . \\
\hline & & $\mathrm{N}$ & 150 & 150 & 150 \\
\hline
\end{tabular}

Table 10: Relation between individual dietary diversity and health problem of the respondents.

\begin{tabular}{|c|c|c|c|c|c|}
\hline \multicolumn{6}{|c|}{ Correlations } \\
\hline & & & $\begin{array}{c}\text { Individual } \\
\text { dietary diversity }\end{array}$ & $\begin{array}{l}\text { Suffered from general } \\
\text { health problem }\end{array}$ & $\begin{array}{l}\text { Suffered from } \\
\text { reproductive } \\
\text { health problem }\end{array}$ \\
\hline \multirow{9}{*}{$\begin{array}{l}\text { Spearman's } \\
\text { rho }\end{array}$} & \multirow{3}{*}{$\begin{array}{l}\text { Individual dietary } \\
\text { diversity }\end{array}$} & $\begin{array}{l}\text { Correlation } \\
\text { Coefficient }\end{array}$ & 1.000 & -.147 & -.045 \\
\hline & & Sig. (2-tailed) & . & .072 & .585 \\
\hline & & $\mathrm{N}$ & 150 & 150 & 150 \\
\hline & \multirow{3}{*}{$\begin{array}{l}\text { Suffered from } \\
\text { general health } \\
\text { problem }\end{array}$} & $\begin{array}{l}\text { Correlation } \\
\text { Coefficient }\end{array}$ & -.147 & 1.000 & .156 \\
\hline & & Sig. (2-tailed) & .072 & . & .056 \\
\hline & & $\mathrm{N}$ & 150 & 150 & 150 \\
\hline & \multirow{3}{*}{$\begin{array}{l}\text { Suffered from } \\
\text { reproductive health } \\
\text { problem }\end{array}$} & $\begin{array}{l}\text { Correlation } \\
\text { Coefficient }\end{array}$ & -.045 & .156 & 1.000 \\
\hline & & Sig. (2-tailed) & .585 & 0.056 & . \\
\hline & & $\mathrm{N}$ & 150 & 150 & 150 \\
\hline
\end{tabular}

\section{Discussion}

In order to have a better-earning opportunity poor family from rural areas of our country migrate to cities and begin to live in slum areas. In a tiny period, these poor rural people become accustomed to living in such places and make temporary domicile there. As income earning opportunity is very limited in rural areas, growing number of rural people have migrated and settled temporarily in urban slums in recent years. The slum areas are mostly located by the side of roads and railways, in government khas (free) land and even on platforms erected on water bodies. Adolescence, a period of transition between childhood and adulthood, occupies a crucial position in the life of human beings. The poor nutritional status of adolescent girls has important implications in terms of physical work capacity and adverse reproductive outcomes [6]. Adolescents have specific health and development needs, and many face challenges that hinder their well-being. The findings of this study are kind of similar to some of the previous studies.

In this study, the majority of the girls (50\%) were in age group 10-13 years (early adolescence), while $30.7 \%$ were in 


\section{Global Journal of Reproductive Medicine}

age group 14-16 years (middle adolescence) and 19.3\% were in the age group 17-19 years (late adolescence). About $24 \%$ of the adolescent girls were garments worker. The educational status of the girls was quite satisfactory as the majority of the girls (72.7\%) were students. $18 \%$ of the family had monthly income more than 25000 takas and $26.7 \%$ of the family had monthly income less than 14000 takas. Another study found that $51 \%$ of the household of the adolescent had monthly family income more than 20,000 takas and $11.4 \%$ had less than 10,000 takas [7]. Majority of the girls (58.7\%) suffered from general health problem and $34 \%$ of them suffered from reproductive health problem during last three months. Most of the girls (49\%) suffered from fever and 11\% of the girls suffered from cough. Another study found that $17 \%$ of the adolescent girls suffered from fever and $8 \%$ of the girls suffered from caught [8].

This huge difference between the two studies probably because the corresponding study was done in the winter season. This study found about $70 \%$ of the respondents suffered from abdominal pain and $6.1 \%$ of the girls suffered from irregularity during menstruation. Another study found a similar percentage of irregular menstruation [8]. Average age of starting menstruation was found 12 years. This finding was almost similar to a different study where the mean age of starting menstruation was 13 [9]. This study found that almost $34.2 \%$ of the girls did not seek treatment for their health problems and those who sought for treatments are mainly dependent on pharmacy attendance (61.7\%) for medicine. $67 \%$ of the girls used cloth during menstruation and $90.5 \%$ of the respondents said that they did not follow proper procedure to clean the cloth. About $85.3 \%$ of the adolescent girls did not take any vaccination. Half of the girls (54.3\%) said that they isolated themselves and $57 \%$ of the girls said they avoid food items during their menstruation. As the adolescent girls in slum live in a very crowded area and they have very scarce financial supports and adequate knowledge, they face enormous trouble to lead a healthy life. Their health seeking behaviors are also affected by their poverty, knowledge, time allocation and availability of infrastructure.

In our country, the current healthcare systems scarcely address the health needs of adolescents. Furthermore, they are inadequately informed about the symptoms and consequences of reproductive health conditions. Another cross-sectional survey was conducted from November 2006 to March 2007 at two selected study areas (an Upazila of Sylhet division and a slum of Dhaka city) with 800 unmarried female adolescents aged 12-19 years. According to this study, approximately $50 \%$ of the sample reported experiencing menstrual problems in the last year. The predominant problems reported by participants included lower abdominal pain, back pain, irregular menstruation, and excessive bleeding during menstruation. Irrespective of the study area, only $40 \%$ of the female adolescents with menstrual problem sought treatment from qualified physicians [10]. Another study reveals that encouraging factors of health-seeking behaviors are: healthconscious (37\%), beliefs in improved care $(29 \%)$, better education (21\%), knowledge of health and illness (8\%).
A little payment as doctor's fees influenced a large number of women (175 out of 357 ) to treat their illness in government hospitals. Other factors that encouraged them were family health consciousness (38\%) followed by husband's income (9\%), husband's knowledge of illness (7\%), and affordable costs (2\%). The study also found some discouraging factors of healthcare seeking behaviors these are: less information about essential services (55\%), ignorance of illness (24\%), personal dislikes to government hospitals $(16 \%)$, shyness to disclose diseases complications (3\%), and physical disability. The factors e.g. asymmetrical attitudes towards women $(34 \%)$, lack of husband permission (33\%), male doctors to female patients (22\%), unemployment and dependency (15\%) (Rahman et al, 2016) [11]. In our country, there is a very low facility for the treatment of the adolescent girls. Both Directorate General of Health Services and Directorate General of Family Planning implement reproductive health services through their programs on maternal, neonatal, and child health ( $\mathrm{MNCH})$, reproductive and sexual health, including family planning. Married women are the main beneficiaries of these services. In Bangladesh, however, unmarried female adolescents receive limited attention for healthcare issues by these existing programs (Ahmed et al, 2007) [12]. Some of the respondents hesitate to share their reproductive health problems.

\section{Conclusion}

This study concluded that one third of the girls suffered from reproductive health problem and majority of them sought pharmacy/quack dependent treatment.

\section{References}

1. Kamal SM, Islam MA (2010) Contraceptive use: socioeconomic correlates and method choices in rural Bangladesh. Asia Pac J Public Health 22(4): 436-450.

2. World Health Organization (2014) WHO Country Cooperation Strategy: Bangladesh 2014-2017.

3. Nolen H S (2001) Gender differences in depression. Current directions in psychological science, 10(5): 173-176.

4. Rahman M (2015) Juvenile delinquency in the slum community: A study on Tejgaon area in Dhaka city (Doctoral dissertation, University of Dhaka).

5. World Health Organization. Reproductive Health (2010) Medical eligibility criteria for contraceptive use.

6. Haboubi GJ, Shaikh RB (2009) A comparison of the nutritional status of adolescents from selected schools of South India and UAE: a crosssectional study. Indian J Community Med 34(2): 108-111.

7. Kurshed AAM, Rana MM, Khan S, Azad TA, Begum J, et al. (2010) Dietary intake, physical activities and nutritional status of adolescent girls in an urban population of Bangladesh. Ibrahim Medical College Journal 4(2): 78-82.

8. Alam N, Roy SK, Ahmed T, Ahmed AM (2010) Nutritional status, dietary intake, and relevant knowledge of adolescent girls in rural Bangladesh. J Health Popul Nutr 28(1): 86-94.

9. Chowdhury S, Shahabuddin AK, Seal AJ, Talukder KK, Hassan $Q$ et al. (2000) Nutritional status and age at menarche in a rural area of Bangladesh. Ann Hum Biol 27(3): 249-256.

10. Caswell JA, Yaktine AL, National Research Council (2013) Individual, Household, and Environmental Factors Affecting Food Choices and Access. 
11. Rahman MM, Rahman MH, Parveen SS, Giedraitis VR (2016) Health Seeking Behavior and Healthcare Access to Married Women in Bangladesh: Encouraging and Discouraging Factors. South Asian Journal of Participative Development, 16(2): 5.
12. Ahmed SM, Begum HA, Afsana K (2007) Maternal, neonatal and child health programmes in Bangladesh.

Your next submission with Juniper Publishers
will reach you the below assets
- Quality Editorial service
- Swift Peer Review
- Reprints availability
- E-prints Service
- Manuscript Podcast for convenient understanding
- Global attainment for your research
- Manuscript accessibility in different formats
( Pdf, E-pub, Full Text, Audio)
- Unceasing customer service
Track the below URL for one-step submission
https://juniperpublishers.com/online-submission.php

